Original Article

Received/Accepted

Dates

10.09.2021/20.10.2021

DOI

10.52096/jsrbs.6.1.7.13.31
Journal of Social Research and Behavioral Sciences

Sosyal Araştırmalar ve Davranış Bilimleri Dergisi

ISSN:2149-178X

Volume: 7 Issue: 13 Year: 2021

\title{
Türkiye’de Siyasal İletişimin Gelişim Süreci
}

Umut Y1ldiz

Millî Eğitim Bakanlığı Eğitim Yöneticisi

umutyildiz80@hotmail.com

ORCID:0000-0001-2352-3199

\section{Özet}

Günümüz koşullarında yeni medyanın, geleneksel medyanın araç ve gereçlerine oran ile çok daha fazda kitlelere ve kesimlere ulaşma imkânı bulduğu görülmekte. Bu imkân sayesindedir ki, yeni medya anlayışının en önemli icatları arasında sayılan internet; hayatın tüm sahalarında, hatta en kılcal hususlarda bile çok değişik amaçlar için kullanılmakta.

Son devirlerdeyse dijitalleşme, özel olarak siyasî partilerce siyasî seçimlerde kampanya ve girişimler yönünden siyasî iletişimsellik amacı ile yoğun biçimde talep görmektedir. İnternetteki ortam siyasî parti ve grupların paydaşı olan kişi ve kurumlar ile buluşarak onlar ile iletişim kurmasına aracı olan mühim bir mecra olarak karşımıza çıkmakta. Bu vesileyle siyasî parti ve grupların internetteki ortam özelindeki iletişimsel gayret ve çabaları seçimle alakalı kampanyaları döneminin haricindeki süreçlerde de istikrarlı ve güçlü bir şeklide sürdürülmekte.

$\mathrm{Bu}$ çalışmada, siyasî parti ve grupların siyasî katılım ve iletişim süreçlerini yeni medya örüntülü dijital teknolojinin sağlamış olduğu imkanlar ile ne ölçüde yetkin bir biçimde kullanabildikleri üzerinde durularak yeni medyanın siyasete katkıları aktarılmaya çalışılmıştır. Çalışma çerçevesinde siyasî iletişimsellik anlayışının kavramsal yapısı ile yeni medya örüntülü dijitalleşme sürecinin devinimsel sınırları irdelenmiş, siyasî partilerce bunların kullanımın amaçsal durumu açıklanmaya çalışılmıştır.

Anahtar Sözcükler: Yeni Medya, Siyasî partiler, Siyasî İletişim.

\section{Development Process of Political Communication in Turkey}

\begin{abstract}
In our age, new media provides the opportunity to reach much wider masses and segments in proportion to traditional media tools and equipment. Thanks to this opportunity, the dijital, which is accepted as the most
\end{abstract}


important invention of the new media understanding, is used for many different purposes such as politics, entertainment, communication, commerce and education.

Recently, the dijital has been used extensively for political communication, especially by political parties in terms of political election campaigns and initiatives. The dijital environment appears as an important medium that enables political parties and groups to meet and communicate with their stakeholders. For this reason, the communication work of political parties on the dijital should continue in a stable and determined manner in the process other than the election campaigns.

Here, it is aimed to reveal how politically effective the political participation and communication processes of political parties and groups are with the opportunities provided by the new media patterned dijital. Within the framework of the study, the conceptual structure of political communication and the new media patterned dijital process were examined, and the purposeful status of their use by political parties was tried to be explained.

Key Words: New Media Political Parties Political Communications.

\section{Giriş}

Siyasî iletişimsellik anlayışı çokça öge ve boyut barındıran, disiplinlerarası bir çalışma sahası biçiminde dikkat çekmekte. Hayat pratiği ve teoriğindeyse çokça kesim için olmaz ise olmaz bir etkililik sahası şekilinde varolmakta. Siyasî iletişimsellik anlayışı çağımız sosyopolitik koşul ve durumlarında mühim oranda medyanın içersinden geçerek gerçekleştirilmekte.

Dijital iletişim tekniğiyle benzer zamanda yeni medya biçiminde yükselen bir güç olan internetse değişik siyasî kuramcı ve kişilere bu süreci sunduğu yeni imkan, taktik ve stratejiler ile kurgulanılması imkanı tanımakta, daha da fazda olarak siyasî iletişimsellik anlayışına farklı bir uzanım katmaktadır.

Siyasî hayat sahasıyla yoğun bir ilişkisellik ortaya koyan bu yeni boyutta, siyasî sahada yetkin insanlar ve siyasî partiler geçmişine nazaran mühim faydayla çok değişik etkinlikte bulunarak müspet neticeler elde etmektedirler. Geleneksel medyada fikrini duyurmak anlamında kuvveti bulunmayan siyasî partilerle çeşitli hususlarda müspet ve menfî düşünce ve görüşe haiz insanlar dijital teknolojinin ortaya koyduğu araç ve gereçler sayesinde geleneksel medyanın çok değişik sebeplerden kaynağını bulan yine çok değişik ketlemelerine maruz kalmaksızın sesini duyurmakta, siyasî konularda nicel manada hür mütalâa imkanı bulmaktadırlar. 


\section{Türkiye’de Siyasal İletişimin Gelişim Süreci}

Siyasî parti ve kişiler, seçmen vatandaşlarına web aracılığı ile direkt olarak seslenebilmekte. Menfaatleri yönünde seçimle alakalı kampanyasındaysa bloglar, web, forumlar v.s. dijital araç ve gereçleri kullanmakta. Siyasî partilerin taraftarı olanlar, gösteriler ve girişimlerle ananevî etkinlik ve çalışmaları dijital tekniğin imkanları ve farklı yöntemleriyle düzenlemektedirler.

Yeni medya anlayışında siyasî parti ve kişilerce meydana getirilen siyasî iletişimle alakalı yöntemler ve burada kullanılan siyasî partiler, aktörler ve vatandaşlar uzanımları bakımından

ülkemizin yeni medyayla örüntülü siyasî iletişimsellik tipolojileri irdelenmiştir. Dolaysıyla yeni medyaya dayalı dijital tekniğinin gelişimsel süreçlerinin ülkemizde ne türlü kurgulanıldı̆̆ı; imkan, taktik ve beklenti yönünden araştırma konusunu oluşturmaktadır.

\section{Siyasal İletişimin Kavramsal Çerçevesi}

\section{Siyaset ve İletişim}

Siyaset, toplulukların otorite olma eylemi ve fikirler ardında örgütlü olma çabası sayesinde hayatın bir parçası şekline gelmiş bulunmaktadır. İletişimse insanlığın var olduğundan bu yana hayatın dahilinde fark edilebilen ve edilmeyen kısımları ile hep var olmuştur. Siyasî iletişimsellik kanallarını açıkça kavramak ve yorumlamak amacı ile bunları biraz daha derinlemesine ele almak, müşterek noktaya yönelik ilerlemek meseleyi daha açıklayıcı hâle getirecektir (Özsoy, 2009). Arapça'dan kökenini almış bir ifade olan siyaset atın eğitilmesi manasında kullanılır (Kışlalı, 2000). Sözcüğün kökeni irdelendiğinde, mazmun olarak Doğulu medeniyetlerde devlet aygıtının yönetimi ile alakalı şeklide kullanıldığını görmekteyiz. Batılı dillerdeki karşılığında ise siyaset ifadesi Yunanca'da police, polteie, politican, politiken gibi ifadelerden kaynağını almakta ve buradan türemektedir (Erdoğan, 1997).

Çağımızda siyasetle politika ifadeleri hususunda değişik tanımlamaların yapılmakta olduğu görülmektedir. Bunların bir çok tanımlarını yapmak mümkündür. Birinci olarak özelikle siyasî parti ve kuruluşlarca meydana getirilen tanımlarda politika, siyasî iktidarların elde edilmesine dönük eylemin ve söylemlerin bütünüdür. Siyasî partilerce bu manadaki siyaset anlayışının başlıca amacıysa, siyasî yetkeyi elde etmek ve ona müşterek olmaktır. İkinci olarak bir örgüt veya bir kuruluşun ve onun yöneticisi olan kişilerin mühim hususlarda benimsemiş olduğu tutumlar, yönelimler, izledikleri yollar ve yöntemlerdir (Devran, 2004). 
Bir görüşe ve anlayışa göreyse, siyaset/politika, topluluktaki değişik sınıflar, çıkarlar ve taleplere haiz insanlar arasındaki paylaşımların ve bölüşümlerin bir mücadelesidir. Bu değişik menfaat ve düşünce guruplarının karşı karşıya gelmesinden kaynağını bulan çatışmanın, politikanın temel özeliğini oluşturduğunu belirtmek mümkündür. Topluluktaki değerlerin ve kıt kaynakların paylaşılması çabası bu çatışmalarınn sebebini oluşturur iken, paylaşımı rahatlaştırmanın yolu ise iktidara haiz olmak ve gücü ele geçirmekten geçmektedir (Özkan, 2004).

Dyken siyaseti kamu oyunu ilgilendirmekte olan problemlerde şahsî önceliğini benimsetme, uygulatma, başkalarının önceliğinin gerçekleştirilmesinin önüne geçmek üzere değişik kişi ve kuruluşların yürüttüğü mücadele şeklinde tanımlamakta ve bu anlayışı benimsemektedir. Easiton'a göreyse, maddesel ve muhayyel değer ve yargıların yetkeye dayalı şekilde dağıtılması vetiresine siyaset denmektedir (Turan, 1999).

Weber'e göreyse siyaset, devletler içerisinde ve de erkler dahilindeki guruplar içerisinde gücü müşterek kullanmaya ve de dağılımını tesirlemeye çalışmaktır (Weber, 1993). Siyaset, kamuyu ilgilendiren olgudur. Weber, siyaseti, insanlığın topluluk dahilinde hayatına bağlı şeklide belirmekte; çok sayıda bireylerin bir arada yaşamaları bir başına siyasetin varoluşunu izah etmeye kafi gelmez. Sözü edilen, çok sayıda bireylerin rasgele bir arada bulunulması değildir elbet, bu bireylerin değişik bağlar ile birbirine bağlanma, tesirleşimde bulunma, diğer benzeş birimlerin önünde üyesinin değişik bir kimliğe haiz olduğunu algılamalarıdır (Turan, 1999).

Siyaset kavramı, TDK sözlüğündeyse, devlet iş ve işlemlerini yönetmek anlayışı şeklinde yer almaktadır (TDK, 2000). Yalnız siyasî yapı, siyasî sistemin üzerinde tesiri değişen karmakarışık birimlerden ve faaliyetleren oluşmaktadır ki, bu siyaseti kavramak anlamında verimsiz kalmakta. Siyaseti sadece devleti yöneten başkanın, başbakanın ve parlamenterin çabaları şeklinde yorumlamak yetersiz bir ifadedir. Devletler arasındaki ilişkiselliğin söz konusu yapıldığı, bazı kişilerin her hangi bir durumu protesto ettiği ferdî bir harekettir. Her ikisi de hedefin siyasî yapı üzerinde bir tesir yaratttığı göstermektedir ki bu önemli bir durumdur (Weber, 1993).

Siyasetin değerler anlayışına bağlı tanımının bir çoğunda kudret, yetke, kuvvet ve devlet gibi kavramın bulunduğunu ve siyasetin bu ifadelerden beslenildiği görülmektedir. Gerçekteyse siyasî eylem ve söylemi, siyasî haricindeki durumlardan ayırmış olan en mühim unsur yetke ifadesidir ve bu ifade zoraki unsura baş vurmayı ve bununsa devlet aygıtının yetkesinde bulunulması anlayışını içermektedir (Mimtad, 1987). 


\section{Türkiye’de Siyasal İletişimin Gelişim Süreci}

İletişimse insanî ilişki biçimlerinin var olması ve gelişimini temin eden olgulardır. Birbirleri ile haberleşen diğer canlılardan bigâne şeklide insan, iletişim kurar iken normlarını, değerler sistemini, kültürel yapısını meydana koyar. Değişik kaynakta iletişimle alakalı fazlaca ve bambaşka içeriklerde ifadeler ve tanımlama biçimleri yapılmıştır (Üste, 2000).

İletişimin tılsımlı kuvvet olduğunun önemini kavrayan, iletiyi süzgeçlerden geçirmek, her şeyden evvel düşünmek ve her iletinin amaçsallığının farkındalığına varmak, buna vakit bulmak, bu hususta enformasyon edinmek, esas kaynakları değerlendirebilme gerekli ve önemlidir. Aristo'dan Chomsiky’e dek iletişimle alakalı araç ve gereçlerinin, insanoğlunun tüketimsel alışkanlıklarından haiz bulunulması elzem olan görüntülerine, çevreleri ile kurduğu ilişkiye ve içerisinde yer alacakları guruplara dek pek çok hususta düşüncesini tesirlediği göz ardı edilemeyecek kadar elzemdir (Peltekoğlu, 2010).

İletişimin kullanılışına yöneldiğimizde, Tanakard ile Severlin (1994), bunları; kişi ve gurupların içsel iletişimleri, kişiler arasındaki iletişimler, guruplar arasındaki iletişimler, kitleler arasındaki iletişimler ve kişi dışı iletişimler şeklinde bazı ifadeleri kullanma suretiyle belirtmiştir. İçsel iletişimler, kişiler arasındaki iletişimlerin içsel düşünüm vetiresidir. Kişiler arasındaki iletişimlerse yalın şeklide iki ya da daha fazda birey arasındaki iletişimsel süreç şeklinde tanımlanmaktadır. Kitleler arasındaki iletişimlerse umumi manası ile medya sektöründeki iletişimle ilgilidir. İşitselliğe, görselliğe, yazıya ve söze ait araçlar ve gereçlerle yapılan iletişimsellik çeşididir. İnterneti, televizyonu, radyoyu, gazeteyi esas kitleler arasındaki iletişim kanalı ve araçları olarak karşımıza çıkaran durum da dijital dönüşüm sürecidir.

\section{Siyasal iletişim kavramı}

Siyasî iletişim, toplulukla alakalı durumların ve gerçekliklerin umumiyetle çok yönlü perspektifli ve karmakarışık bir özelik taşıdıkları, bu özelikleri dolaysıyla tek yönlü perspektifli ve basit yorum kalıp ve sınırlarına sığmasının mümkün olmayacağı düşüncesiyle müşterek yazgıyı paylaşmaktadır (Yavaşgel, 2004). Ayrıca siyasî iletişimle alakalı ifade, her iki bileşeni az ve de çok geniş ve değişik tanımlara açıldığı için net ve yalın bir biçimde tanımlamak son derece güçtür. Öylesi bir kavramsallık ve kuramsallık dahilinde olguya dönük net bir konsept sinır belirleyebilmek oldukça güç bir durumdur. Siyasî iletişimsellik anlayışına ilişkin yazınlardan hareket ile siyasî iletişimsellik anlayışına dönük değişik düşünürün, kuramcı ve araştırıcıların 
görüş ve düşünce ürününün değerlendirilmekte olduğu siyasî iletişimle alakalı kavramsallık süreci; akademi, olgu, saha, uygulamalar bütünü şekilinde betimlenilmektedir (Kalçık, 2007).

Siyasî iletişimi tek bir cümleyle anlamlandırılması güç bir durumdur. Kavramsallığı meydana getiren ifadelerin sınırındaki genişliği, meydana gelen tanımı kaçınılmaz şeklide karmakarışıklaştırmaktadır (Divanoğlu, 2007).

Deniton ve Woodaward siyasî iletişimle alakalı kavramsallığı kamu oyu kaynaklarına tahsis edilenler hakkında kamusal tartışmalar, resmî yetkeler ve resmî yaptırımlar şeklinde tanımlamaktadır. Buradaki tanımsa, siyasî iletişimsellik anlayışını siyasetle alakalı bileşene yaklaştırmaktadır ki, bu da siyasî iletişimi değerli kılmaktadır (Domenach, 1995). Deniton ve Woodaward siyasî iletişimle alakalı kavramsallı̆̆ göndericinin siyasî çevçeveyi tesirleme niyetleri ile bütünleştirmekte, bu manada iletişim ifadesini siyasî yapan canalıcı etkiler iletinin kaynăğ değildir, onun içerikleri ve erekleri olmakta. Tanımsa sözlüce ve yazılıca siyasî retorikleri kaplamakta, yalnız sembolik iletişimsellik sürecinin bütünüyle anlaşılması ve yorumlanmasını sağlayabilecek yüzeysel iletişimsellik davranımlarını içerememektedir ki bu olguyu ifadenin siyasî terminolojik düşüncesiyle kurgulanılmış bulunulması etkiyi açıklamaktadır (Domenach, 1995).

Graeber'se retorikle değil, beden dili gibi dil ötesi, kargaşa ve protesto tarzında siyasî davranımları içermiş olan siyasî dil ifadesiyle bütünü çevreleyen bir tanımlamak modeli önermektedir ki, bu yaklaşım da siyasî iletişimi değerli hale getirmektedir (Bongrand, 1992).

McNeair, Deniton ve Woodaward'ın çalışmasından hareketle siyasî iletişimsellik anlayışının özeliğinin üzerini kalın harflerle belirtmekte, kavramıysa basitçe siyasî mefhum hususunda amaçlı ve araçsallı iletişim modeli şekilinde tanımlamaktadır ki ve şu 3 yargıyı içermektedir (Bongrand, 1992):

a. Siyasetçilerce iletişimselliğin tüm formlarına bireysel amaç ve ilkeleri başarabilmek ereği ile girişilmekte.

b. İletişimsellik kişiler, seçmen ve köşe yazarı gibi siyasî olmayanları işaret etmekte.

c. Haber bülteni, baş yazılar, siyasî konuşmaların özsel biçemleri söz konusu kişileri ve etkinliliği hususunu içermekte.

McNeair bu tanımlamanın tüm siyasî söylemleri kaplayacağını belirtmekte. Dolaysıyla McNeair'a göreyse siyasî iletişimsellikle sadece Graeber'in belirttiği yazılı ve sözlü tümceler değil de, giyimler, makyajlar, saç stilleri, logoların tasarımları tarzındaki göstergenin görsel manası şekilinde tümü siyasî imajları ve kimlikleri oluşturmaktadır (Çavdar, 2004). 


\section{Türkiye’de Siyasal İletişimin Gelişim Süreci}

Simith, siyasî iletişimselliğin ifade tarzında Deniton ve Woodaward gibi siyasetin uzmanlarından hareket etmiştir. Ona göreyse siyasî iletim kavramı, topluluğun bir kesiminin ve kuvvet ilişkisinin müşterek bir zeminde ve zamanda uzlaştırılmasıysa; siyasî iletişimsellik kavramı, müşterek sembol ve ilkeleri oluşturmak, yorumlama ve müzakere yürütmek yöntemi ile antlaşma ortamında uzlaşmak süreçlerini belirtmektedir. Meydana getirilen iş ve işlemlerse siyasî iletişimsellik aracılığı ile yürütülmekte, siyasetin kendisiyse siyasî iletişimsellik aracılığı ile sürdürülmektedir (Y1ldiz, 1994).

Bilumler ve Gurewitch’te kurgusal bakış açısı ile siyasî iletişimsellik, sistemlerde, siyasî arenada ve medya arasında derinleşen sınırlarda siyasî iletilerin üretilme ve süre gelmesi şeklinde yer almaktadır. (İşler, 2007) diyerek siyasî iletişimselliği sistemdeki apsisler esasından ifadelendirmektedir.

Nimimo ve Swanason ortaya koydu konsept ile esasında siyasî iletişimsellik sahasını izah etmekte. Her ikisine göreyse siyasî iletişimsellik ifadesi süreç şekilinde değişik ve disiplinlerarası bir irdelemedir. Bu tarz sahaların bir çoğunda olduğundan siyasî iletişimsellik sahası, manası, kimliği ile alakalı biribirisi ile örtüşmeyen teoriler, yaklaşımlar, gündemler ve kavramlar ile yaşatılmaya çalışılan sahadır. Bu saha, sosyolojinin genel varsayımsal olgusundan ziyade iletişimsellik süreci ile siyasî sürecin arasında yer alan bağlar hususunda yaklaşımlar sergileyebilen çalışmalar ile oluşturulmaktadır (Sönmez, 2009).

Benzeş şeklide Franklinn de adlandırmasını siyasî iletişimsellik sahasını açıklamak yolu ile oluşturmaktadır. Franklinn'in ifadesi ile siyasî iletişimsellik sahası medyada ve sistemlerin bölgesel, millî ve uluslar arası etkileşimleri üzerinde çalışmaktadır (Zürcher, 2004). Siyasî iletişimsellik aşağıdaki çözümlemeler üzerine odaklanmaktadır:

a. Medyadaki siyasî iletişimsellikle alakalı içerikler,

b. Sözkonusu içeriklerin oluşumuna katkı sağlayan ajan ve aktörler,

c. Siyasî iletişimselliğin içeriklerinin siyasî geliştirici kişiler üzerinde yer alan tesiri,

d. Siyasî iletişimsellik sistemlerinin medyadaki sistemler üzerinde yer alan tesiri,

e. Medyadaki iletişim sistemlerinin siyasî alandaki sistemler üzerinde yer alan tesiri (Zürcher, 2004).

İfadelerin temel hatlarıyla değerlendirilebilmesinde hareket ile bir genellemek yapılacak olursa siyasî iletişimsellik; siyasî kişilerin, ereğini gerçekleştirebilme için siyasî iletilerini topluluğa 
ulaştırabilme gayesiyle tüm medya organlarından yararlanmalarını, dolaysıyla siyasî anlayış ve iletişim kanallarının iç içe geçtiği kesişimleri anlatmaktadır.

\section{Türkiye'de Siyasal İletişimin Gelişim Süreci}

Cumhuriyet'in yönetsel idaresinin kuruluş süreciyle gelişen devrimsel çalışmalar, kısa sürede tüm ülkenin geneline yayılarak planlı siyasî iletişimsellik faaliyetlerinin başlamasını gerektirmiştir. Cumhuriyet'in kurucusu Mustafa Kemal Atatürk liderliğinde yönetilen devrim çalışmaları çokça propaganda tekniğinin ve yöntemimin kullanılmasıyla tüm kesimlere benimsetilmeye uğraşılmıştır. Mustafa Kemal Atatürk'ün bizzat verdiği nutuklardan, hayatın tüm alanlarına dek her şeyi devrimi ve çağdaş yaşamı halkın geneline aktarmak, izah etmek için siyasî iletişimsellik aracı şeklinde kullanmıştır. Devrimlerin propagandasının yapılabilmesinden çok, devrimsel terbiyenin halka verilmesine uğraşılmış, meselesinde toplumsal bütünleşmenin eğitimi meselesine dönüştürülmesine çalışılmıştır. Cumhuriyet'in ilk yıllarında radyo aygıtının mahdut sayıda insanlarda yer alması, okuma yazma oranındaki düşüklük düşünüldüğünde, anlatma temelli iletişimsellik taktiği izlenilmiştir (Çavdar, 2004).

Profesyonel siyasî iletişimlerden bahis edilemese de, yapılacak olan her çalışma merkezî bir idareden planlanmış ve uygulanılmıştır. Buradaki çalışmaların Cumhuriyet'in ilk planlı siyasî iletişimsellik çalışmaları şeklinde kabul edilebilir.

Ülkemizde siyasî iletişimselliğin zuhuru çok partili siyasete geçmek süreci ile imkan dahiline girmiştir. Tekpartili siyasetin var olduğu Cumhuriyet'in ilk döneminde doğal şeklinde siyasî çekişme ve siyasî iletişimsellik anlayışının gerekliliğini meydana getiren ortam da yer almamakta idi. Çok partili siyasete geçmeden sonraysa yaşanılan en erken çok partili seçim 1950 senesinde gerçekleşmiştir. Cumhuriyet'in ilk döneminde en tesirli kitlesel iletişimsellik aracı olan radyolar, ülkemiz genelinde gerek siyasî iletişimsellik anlayışının başlangıç döneminde gerekse de gelişimsel süreçlerini süratlendirmede mühim vazifeler görmüştür (Uztuğ, 1999).

Çok partili siyasî ortama geçme ile beraber Demokrat Partinin seçimle alakalı yaptığı çalışmaları, düzenlediği gezintileri, mitinglerle gösterileri ve toplantılar halkın siyasî duyarlılık anlayışını arttırdı. Seçimle alakalı kampanyaları, bu zeminiyle siyasî sistem ve demokrasi yönünden mühim bir fonksiyona haizdir. Ülkemizde seçimle alakalı kampanyaların özgür kültürün ve siyasî katılmasın tekrar biçimlenişinde benzeş bir model olduğu pekala söylenebilirdir. 2. Dünya 


\section{Türkiye’de Siyasal İletişimin Gelişim Süreci}

Savaşında esen özgürlük ortamı dahilinde sevimli karşılanan demokrasi ifadesi, Cumhuriyet Halk Partisinin göz önünde yer alacak ilk dikkate değer partinin sembolik ismi şeklinde benimsenmiştir (Uztuğ, 1996).

DP’nin ülke çapında gerçekleştirdiği tesirli iletişimsellik çalışmaları, ferdî görüşmeler ve hâlen isimleri zihinlerde kazınan sloganlarıyla yönetim erkine geliş süreci ülkemizde siyasî iletişimsellik anlayışının ilerlemesinin esasını meydana getirmiştir (Çobanoğlu, 2007).

Süreçleri izleyen 60'lı ile 70'li senelerde meydana getirilen seçimlerde radyo unsuruna ilave şeklinde gazeteler ve dergiler de siyasî iletişimsellik bakımından yetkin rol oynamaya başlamıştır. Gazeteler ve dergiler, seçimler dönemlerinde miting, gösteri ve gezileri izlemekte, siyasî liderleri ve adayları seçmenlere tanıtmakta, konulara dönük duruş ve tavırlarını iletmekte idi. $\mathrm{Bu}$ da gazeteleri ve dergileri en yetkin iletişimsellik araçları şeklinde getirmiştir (Çobanoğlu, 2007).

Siyasî iletişimsellik anlayışının en yetkin güçlerinden birisi olan televizyonun 1968 senesinde TRT'nin tecrübe yayımları ile evimize girişi ve 1970 senesinden tüm ülkeye yayılması ile yepyeni bir sürecin eşiği başlamıştır. Yalnız bu süreçlerin siyasî iletişimsellik bakımından ilerleyişi süratli gerçekleşmemiştir (İçel, 1998).

Televizyon, yayıldığı tüm ülke genellerinde siyasî iletişimsellik çabalarını ve seçimlerle alakalı kampanya ve çalışmalarını radikal bir biçimde tesirlemiştir. Ülkemizdeyse 1970’lerden başlayarak artmaya başlasa da, esas manada siyasî iletişimsellik çabalarında televizyonun faaliyete başlanılması 1990'lardan sonrasında yaşanmıştır. Özelikle TRT'nin güdümünün tökezlemesi ve hususî televizyonların evlere kadar girebilmesi, seçim dönemlerinde benzeri o ana dek görülmeyen siyasî çekişme ortamını da devreye sokmuştur (Özkan, 2006).

Siyasî iletişimsellik tarihimizin ilk profesyonel kampanya gösterimi 6 Temmuz 1978 seçiminde gerçekleşmiştir. Bu seçim döneminde reklam ajansı profesyonel manada siyasî süreç yürütmekle görevlendirilmiştir. Adalet Partisi namına afişler hazırlayan, sloganvari ifadeler bulan, sesli ve görüntülü kaset ve basın ilanları meydana getiren reklam ajansı Cen Ajans olarak karşımıza çıkmaktadır. Bu parti ilk kez gazete ve dergilere reklamlar yayımlamış, sesli ve görüntülü medya anlayışını kullanılmış ve binlerce kasette seçmen kişilerin evlerine gönderilmiştir (Topuz, 1977).

Siyasî seçimlerle alakalı olarak kampanya ve çalışmalarda profesyonel anlayış 7 Aralık 1983 senesinde meydana getirilen milletvekilliği seçimleri ile yapılmıştır. 12 Eylül darbesinin sonrasında demokrasi hayatının askıya alındığı ve tekraren seçimlerinde gerçekleştirilmesine müsaade edildiği bu devirde eski siyasetçilerle partiler yasaklılıklarından dolayı bunların üzerine 
meydana getirilen 4 siyasî partinin ve onlarında yeni önderlerinin liderliğinde gerçekleştirilmiştir (Aziz, 2003).

1986 senesinde gerçekleştirilen seçimlerde ise ilk kez televizyondan siyasî reklam aracı şeklinde faydalanabilme imkânı sağlanılmıştır. Anavatan Partisi ile Sosyal demokrat Halkçı Partisi bu ortam ve imkandan yararlanabilen partilerden olmuştur, siyasî tarihimizin ilk televizyon reklamları bu devirde ilk kez ve son kez yayımlanmıştır. Yoğun süren seçimle alakalı kampanya, çalışma ve mücadeleler neticesinde siyasî tarihimizin en rengârenk slogan, sözleri ve kampanyaları oluşturulmuştur (Özkan, 2006).

1992 senesinde milletvekilliği seçimlerinde, daha evvel Mittearand'a seçimle alakalı kampanyası hazırlamış olan Seguela'nın Anavatan Partisi seçimle alakalı kampanyasına siyasî iletişimsellik müşavirliği yapmış bulunulması ülkemizdeki seçimle alakalı kampanyaları namına çok mühim durum oluşturmuştur. Seguela'nın Anavatan Partisi ile alakalı çalışma ve çabaları ülkemizin siyasî iletişiminde mühim bir misal şeklinde yer bulmuştur (Aziz, 2003).

1991 senesinde yapılan seçimler ülkemizin siyasî tarihî için esas dönüm odaklarından birisidir. İlk kez bu senedeki seçimlerde siyasî partilerce seçimlerde ajanslarla çalışılmıştır (Özkan, 2006). 1991 senesindeki genel seçimleri müteakip diğer siyasî seçimlerinde de siyasî iletişimsellik yönünden ilerleme ve değiş̧imler olmuştur, her seçimde bir köklüye nazaran geliştirilen teknik ve taktikler yer almıştır. Bu ilerleme ve değişimler ise teknolojinin ortaya koyduğu imkanlarla beraber paralel bir durum arz etmiştir. 2002 senesindeki genel seçimleri ile beraber Adalet ve Kalkınma Partisi politik arenaya önemli bir girizgâh yapar iken siyasî iletişimsellik namına da mühim misaller ortaya koymuştur (İşler, 2007).

3 Kasım 2002 senesinde ve 22 Temmuz 2007 senesinde milletvekilliği seçimleri bu hakikati ortaya koyması açısından önemlidir. Siyasî iletişimsellik teknik ve taktiklerini direkt kullanabilen, çözümsel öneri ve beklentilerini kamu oyuna tesirli mesajlarla ifade edebilen siyasî partilerin başarmalı olması kaçınılmazdır. 3 Kasım 2002 senesinde ve 22 Temmuz 2007 senesinde milletvekilliği seçimlerinden bir parti gurubunun tek başına olarak iktidara gelmesi şeklinde ortaya çıkan sonuç hiç kuşku yok ki siyasî iletişimsellik uygulamalarının da büyük payı bulunmaktadır (Özkan, 2006).

Ülkemizde genel ve yerel seçimler devirlerinde meydana getirilen siyasî iletişimsellik çabaları, Batı'lı ülkede meydana getirilen çabalardan birtakım yönleriyle ayırılmaktadır. Öncelikle ülkemizdeki siyasî propaganda devri epeyce neşeli geçmektedir. Oysa Batı'lı ülkelerde siyasî 


\section{Türkiye’de Siyasal İletişimin Gelişim Süreci}

propaganda döneminde siyasî partiler, önderler ve seçmenlerin daha sakin davrandıkları görülmektedir (İşler, 2007). Batı'daki siyasî propaganda çabalarında özel ve genel hususlar özlü, net ve düzenli biçimde seçmen kişilere sunulur iken, ülkemizde mesajlar dizgeli değildir ve anlaşılmasıysa güç ögeler içermektedir. Batı'lı ülkelerinde söylemler hep gelecekteki yaşam için iken, ülkemizde özelikle geçmişteki dönemlerde yapılan çalışmalar gündemlere gelmekte, gelecekteki yaşam hakkında, yani vaatler üzerinde pek durulmamaktadır. Seçmenin geleceğine dönük ümidi ve beklentileri ülkemizdeki siyasî iletişimsellik çalışmalarında genellik ile ihmâl edilmektedir (Tan, 2002).

\section{Sonuç}

Ülkemizde siyasî iletişimsellik çalışmalarının başlangıcı çokpartili siyasî yaşama geçmeyle beraber hissedilmeye başlanılmıştır. Siyasî çekişme ortamının yaşandığg mekanlarda mühim bir modele haiz olan siyasî iletişimsellik anlayışının ülkemizdeki ilk ciddi uygulama safhaları tüm dünyada olduğu gibi siyasî reklam odaklı meydana gelmiştir. 1950'li senelerle 1980'li seneler içersinde siyasî iletişimsellik geçmişine geçmiş olan uygulama safhalarının gelişim seyri, dünyadaki son otuz senelik sürecin içerisinde siyasî iletişimsellik gelişmesi ile paralel gitmemiştir. 1980'de meydana gelen askerî darbenin sonrasında Turgut Özal'ın politika sahasında yerelmasıyla beraber Türkiye'nin siyasî iletişim anlayışında da mühim ilerleme ve değişimler yaşanmış ve bu ilerleme ve değişimler çağımız siyasî iletişimsellik çabalarının gelişmesine imkan sunmuştur.

Yalnızca ülkemiz siyasî iletişimsellik sisteminin içerisinde özelikle siyasî partilerin ve önderlerin siyasî iletişimsellik anlayışına dönük yıllarca süregelen hatalı ve de eksik algıları ilerleme ve değişimler odağında aheste kalınmasına sebebiyet veren etmenlerden önemli bir diğerini oluşturmuştur. Siyasî partilerimizin ve önderlerimizin siyasî iletişimsellik anlayışına yönelik olarak baş vurdukları en mühim çaba şüphesiz siyasî seçimlerle alakalı kampanyaları olmuştur. ABD’deki siyasî partilerin siyasî seçimleriyle alakalı kampanya ve çabaları seçimlerden ortalama 2 sene evvel başlar iken, ülkemiz siyasî partileri ve önderleri siyasî seçimleriyle alakalı kampanya ve çalışmalarına 4 ila 6 ay kala baş vurmaktadırlar. Gelişmişlik düzeyi yüksek olan devletlerin siyasî iletişimsellik yapıları siyasî kurumlarla ve bireylerle tümleşmişken ülkemizde seçimden seçime hatırlanmakta olan bir uygulama şekilinde süregelinmiştir. Hala çokça siyasî partinin ve önderin seçimden seçime baş vurma isteği hissettiği siyasî iletişimsellik kavramı, 2000’li yıllarla 
beraber 1980'li senelerde yaratılan ilerleme ve gelişim süreçlerinin parçası özeliğinde tekraren rağbet görmüş ve revaç bulmuştur. Fakat buna mukabil malum bir takım kalıplar henüz kırılamamış, haiz olunan bir takım eksiklikler ve de hatalı algılar da düzeltilememiştir.

Dünyanın ilerleyen ve gelişen siyasî eğilim ve yönelimleri paralelinde siyasî iletişimsellik anlayışı, siyasî partilerce çok daha mühim bir noktaya getirilmiştir. Siyasî iletişimsellik anlayışı siyasî kurumların ve benliklerin yalnızca seçimler arifesinde, seçimler döneminde değil de, siyasî hayatlarını sürdürdükleri her an muhtaç oldukları bir olgu şekline gelmiştir. Siyasî iletişimsellik bu yönüyle, gelişmişlik düzeyi yüksek olan ülkelerde profesyonel bir sürecin parçası şeklinde algılanmakla birlikte işin uzamanı olan profesyonellerce yönetilmektedir.

Kitlesel iletişim araç ve gereçlerinin dönemsel yetkinliğine, takip edilirliklerine ehemmiyet vermiş olan siyasî iletişimsellik algısı, dijital çağın gelişmişlik düzeyi yüksek olan ülkelerinde kesifçe kullanılması ile beraber kendisine yeni ve mühim bir mecra kazanmıştır. Büyük kitlelerin hayatının bir parçası şekline gelen dijitalleşme dolaysıyla siyasî iletişimsellik anlayışının da mühim bir mecrası şekiline gelmiştir ve son devirlerdeki siyasî iletişimsellik çalışmalarında da bu etkililiğini kanıtlamıştır. Özelikle sosyal medyanın kullanıcısı sayısındaki artış ve buna bağlı şeklinde gelişimindeki hız siyasî iletişimsellik anlayışının dijital ortamdan yeni medya şeklinde yararlanmasını mecburî hâle getirmiştir.

\section{Kaynakça}

Aktaş, H. (2004). Bir Siyasal İletişim Aracı Olarak İnternetin Partilerin Seçimle İlgili Kampanyalarında Yeri. Konya: Tablet Yayınları.

Arık, C. (2000). Siyasal İkna. Ankara: Vadi Yayıncılık.

Atabek Ü. (1999). Akademik Bir İlgi Sahası: Siyasal İletişim. Gazi Üniversitesi İletişim Fakültesi Akademik Dergisi, S: 3, s. 7-11.

Atabek Ü. (2007). İçerik Çözümlemesi İletişim Çalışmalarının Olağan Yöntemi. Medya Metinlerini Çözümlemek İçerik, Göstergebilim ve Söylem Çözümleme Yöntemleri. drl. Atabek, G. ve Atabek, Ü. Ankara: Siyasî Kitabevi.

Aydın, N. (2009). Etkili İletişim Taktikleri. İstanbul: Kum Saati Dağıtım.

Bakan Ö. (2007). Siyasi Partilerin İnternet Sitelerinde Anket Kullanılması. İzmir: Uluslar arası Medya ve Siyaset Sempozyumu, Ege Üniversitesi İletişim Fakültesi. 


\section{Türkiye’de Siyasal İletişimin Gelişim Süreci}

Bayraktutan S. G. (2007). Yeni İletişim Teknolojileri Bağlamında Siyasal İletişime Altyapısı Etnografisi İle Bakmak. İzmir: Uluslararası Medya ve Siyaset Sempozyumu, Ege Üniversitesi İletişim Fakültesi.

Bektaş, A. (2002). Siyasî Propaganda. İstanbul: Bağlam Yayıncılık.

Bilgin L. (2008). Müspet İmaj Yaratmak: Halkla İlişkiler. İstanbul: Kum Saati Yayıncılık.

Bongrand, M. (1992). Politikada Pazarlama. Ersoy, F. (Çev.). İstanbul: İletişim Yayıncılık.

Bülbül A. R. (2000). Halkla İlişkiler ve Tanıtım. Ankara: Nobel Yayıncılık.

Çakan, I. (2004). Konuşunuz Konuşturunuz, Tekparti Devrinde Politikalarının Etkili Silahı: Söz. İstanbul: Otopsi Yayınc1lık.

Daver B. (1969). Siyaset Bilimine Giriş. Ankara: Şerit Yayıncılık.

Doğu B. (2007). Türkiye'deki Siyasî Partilerin İnternet Sitelerinin Gençlere Dönük Enformasyon/İletişim Yükleri Bakımından Değerlendirilmesi. İzmir: Ulusla arası Medya ve Siyaset Sempozyumu, Ege Üniversitesi İletişim Fakültesi.

Eco U. (2001). Açık Yapıt. Savaş, Pınar (Çev.). İstanbul: Can Yayıncılık.

Ersoy A. B. (2007). e-Devlet ve İletişim Teknolojileri İlişkisi: Panel Analizi Denemesi. İzmir: Uluslararası Medya ve Siyaset Sempozyumu, Ege Üniversitesi İletişim Fakültesi.

Ertaş, H. (2000). Kamuoyu ve Kamuoyu Oluşturma Yöntemleri, Konya: Selçuk Üniversitesi Sosyal Bilimler Enstitüsü, Yüksek Lisans Tezi.

Geray H. (2003). İletişim ve Teknoloji Uluslararası Birikim Düzeninde Yeni Medya Politikaları. Ankara: Ütopya Yayıncılık.

Gerbner, G. (2005). Kitle İletişim Araçları ve İletişim Kuramı. Ankara: Ütopya Yayıncılık.

Gürüz D. ve Ana A. (2005). İletişime Yeni Yaklaşımlar. Ankara: Nobel Dağıtım.

İçel, K. (1998). Kitle İletişim Hukuku (4. Basım). İstanbul: Beta Basım Yayım Dağıtım.

Ankara: Nobel Dağıtım.

İnceoğlu M. (2004). Tutum, Algı, İletişim, Ankara: Elips Yayıncılık.

Kağıtçıbaşı Ç. (1999). Yeni İnsan ve İnsanlar Sosyal Psikolojiye Giriş. İstanbul: Evrim Yayıncılık. Kalender A. (2000). Siyasî İletişim/Seçmenler ve İkna Süreçleri. Konya: Çizgi Yayıncılık.

Kentel, F. (2000). Demokrasi Kamuoyu ve İletişime Dair. Birikim Dergisi, S: 30, s. 39-47.

Köklün, B. (2008). Çalışan Kişilerin Performansını Arttırmada Bir Araç Motivasyon ve Motivasyon Teknikleri. Ankara: Atılım Üniversitesi, Sosyal Bilimler Enstitüsü, Yüksek Lisans Tezi. 
Köker, E. (2007). Politikanın İletişimi İletişimin Politikası. Ankara: İmge Kitabevi.

Lang, K. (2005). İletişim Çalışmaları: Kökenleri ve Gelişimi. Ankara: Ütopya Yayıncılık.

Maran R. (1996). İnternet, Güner, O. (Çev.). İstanbul: Pusula Yayıncılık.

Marie, C. J., Claude, E. (1995) Seçimin Sistemi. Kotil, A. (Çev.). İstanbul: İletişim Yayıncılık.

Mc Quail, D. (1994). Kitle İletişimleri Kuramı. Yüksel, A. H. (Çev.). İstanbul: İletişim Yayıncılık. Mutlu E. (2005). Kitle İletişimleri Kuramları. Ankara: Ütopya Yayıncılık.

Okay A. ve Okay, A. (2005). Halkla İlişkiler ile Medya. İstanbul: MediaCat Yayıncılık.

Özüpek, M. N., Altunbaş, H. ve Aktaş, H. (2007). Seçimle İlgili Kampanyalar ve Partilerin İnternet

Siteleri. İzmir: Uluslararası Medya ve Siyaset Sempozyumu, Ege Üniversitesi İletişim Fakültesi.

Peltekoğlu,B. F. (2001). Halkla İlişkiler Nedir?. İstanbul: Beta Yayıncılık.

Severin W. J.; Tanakard J. W. (1994). İletişim Kuramları. Bir, A. A. ve Sever, S. (Çev.). Eskişehir: Anadolu Üniversitesi Yayınları.

Şener, G. (2007). Yeni Bir Sol Kimliğin İnşasında İnternetin Rolü. İzmir: Uluslararası Medya ve Siyaset Sempozyumu, Ege Üniversitesi İletişim Fakültesi.

Tekinalp, Ş. ve Uzun, R. (2006). İletişim Araştırma ve Kuramları. İstanbul: Beta Yayıncılık.

Tikveş, Ö. (2003). Halkla İlişkiler ve Reklamcılık Ana Bilgiler-Uygulamalar. İstanbul: Beta Yayıncilik.

Timisi, N. (2003). İletişim Teknolojileri ve Demokrasi. Ankara: Dost Kitabevi.

Tokgöz O. (2004). Siyasî İletişimi Anlamak. Ankara: İmge Kitabevi.

Topuz H. (2004). Siyasî Reklamcılık: Dünyadan ve Türkiye'den Örneklerle, İstanbul: Cem Yayıncilık.

Uluç G. (2003). Küreselleşen Medya: İktidar ve Mücadele Alanı. İstanbul: Anahtar Kitaplar.

Uslu, Z. K. (2000). Sihirli Değnek Çağdaş İllüzyon Dilemması, Siyasî İletişim. Ankara: 1. Ulusal İletişim Sempozyumu Bildirileri Kitabı.

Yavaşgel, E. (2004). Siyasî İletişim Kavramlar ve Ardındakiler. İstanbul: Ebabil Yayıncılık.

Wilbur, S. (1992). Kitle Haberleşmesi Teorilerine Giriş. Haberleşme Ne Türlü İşler? İstanbul: Der Yayıncilik. 